\title{
Demorphologization and deepening complexity in Murrinhpatha
}

\author{
John Mansfield and Rachel Nordlinger
}

\subsection{Introduction}

Linguistic complexity is often associated with morphology, but it may also be associated with the unravelling of morphology. Hopper (1990) observes that elements of form that were once morphological exponents may over time lose their morphological status and become unanalysable subparts of lexical stems. For example, the final rime of seldom was once an Old English dative suffix *-um (Hopper 1990: 154). Hopper labels the outcome of this process 'demorphologisation', and we here adapt his usage to conceptualize demorphologization as a gradient phenomenon, in which morphological structure becomes gradually blurred over time by the accretion of lexically specific modifications. ${ }^{1}$ Our focus is not on the end-point of this process but the mid-point, where there are morphological 'semi-regularities' that help speakers and learners predict unknown word forms, but which also leave a residue of unpredictability. This type of analogical unpredictability has become a major focus in research on morphological complexity (e.g., Ackerman et al. 2009; Ackerman \& Malouf 2013; Parker \& Sims, Chapter 2, this volume). Other studies have focused on the problem of predicting inflectional exponence for unencountered forms in an open lexical class, though as we argue below, there are some unexamined conceptual issues with the open-/closed-class distinction. In the current study, we focus on predictability in a closed class of finite verb stems, albeit one in which there are large inflectional paradigms, and demorphologization has advanced to the point where analogical predictability from one stem to another is highly attenuated.

Murrinhpatha finite verb stems, known in the literature as 'classifier stems', exhibit semi-regular patterns associated with demorphologization (Walsh 1976;

1 'Demorphologization' is used rather differently by Joseph \& Janda (1988), who use it in reference to regularization of phonological processes such that they become independent of an erstwhile morphological context. 
Street 1987; Nordlinger 2015; Forshaw 2016; Mansfield 2016). We present data on analogical changes observed by comparing recent fieldwork documentation with forms documented some forty years earlier, showing that the process of demorphologization is still underway. Analogical changes show that classifier stem forms are not learnt and memorized as isolated units, but rather that speakers draw on paradigmatic semi-regularities to predict unknown forms. Though the system does not exhibit regular, productive inflection, neither can it be characterized as a set of 'frozen forms'. Rather it is a relational system, and one that is in flux. We treat analogical predictability as a form of linguistic complexity, and show that through ongoing demorphologization, the complexity of Murrinhpatha classifier stems is increasing. We quantify this unpredictability by adapting probabilistic tools developed by Ackerman et al. (2009) and Ackerman \& Malouf (2015). However, while the latter hypothesize limits of complexity for systems of productive inflection, the Murrinhpatha classifier stems are a closed-class system of 1,638 inflectional forms, where semi-regularities aid acquisition and processing, but whole-form memorization may mitigate the requirement for analogical predictability.

Murrinhpatha is a non-Pama-Nyungan polysynthetic Australian language of the Daly River region of the Northern Territory. It has maintained a vibrant speech community some eighty years after its speakers shifted to settled life under the influence of Catholic missionaries (Pye 1972). Murrinhpatha has some of the characteristics, both linguistic and social, that might associate it with the 'isolated, complex' language type proposed in sociolinguistic typology (Kusters 2003; Lupyan \& Dale 2010; Trudgill 2011: 136; Bentz et al. 2015). However it is doubtful that notions of sociolinguistic 'isolation' or 'low-contact' apply in this instance, since evidence points to a tradition of regional multilingualism (Falkenberg 1962: 13; Dixon 2002: 674). A crucial distinction for sociolinguistic typology is that between child-acquired versus adult L2-acquired multilingualism: child multilingualism has been argued to maintain or increase complexity, and adult acquisition to reduce complexity (Thomason \& Kaufman 1988: 65ff; McWhorter 2007 and Chapter 10, this volume; Trudgill 2011: 34). In the case of Murrinhpatha, we know too little of traditional multilingualism to know which is more applicable. However in the post-settlement era (1930s-present) a large number of people from Marri Ngarr, Marri Tjevin, and other language groups have shifted to Murrinhpatha, in some cases learning both languages as children but switching to Murrinhpatha during adolescent years spent in a multi-ethnic school dormitory established by the missionaries (Mansfield 2014: 98). This influx of new speakers has not brought about any drastic simplifications or other language contact effects in the contemporary grammar of Murrinhpatha, although it has led to the demise of the other languages of the region. ${ }^{2}$ In this chapter, we demonstrate more specifically that

\footnotetext{
${ }^{2}$ Note however that the influx of speakers from other language groups may have had some influence on the distribution of sociolinguistic variables (Mansfield 2015a, 2015b: 183).
} 
inflectional changes observed in the post-settlement period do not constitute simplifications, given a definition of complexity as allomorphic unpredictability, and a model of allomorph prediction based on analogical comparison with other lexemes. Given the ambiguity of Murrinhpatha with respect to sociolinguistic typological hypotheses, we do not here pursue the question of whether inflectional complexity depends on social characteristics of the speech community.

The structure of the chapter is as follows. In section 3.2 we outline the phenomenon of lexically specified inflectional allomorphy, which is the specific type of morphological complexity discussed in this chapter. In section 3.3 we discuss hypothesized limits to this type of complexity when applied to large lexical classes. In section 3.4 we provide an overview of the Murrinhpatha verb and introduce the relevant aspects of Murrinhpatha verb inflection, which involves exponence by multiple phonological increments which we label 'intersecting formatives' (cf. 'paradigmatic layers' in Parker \& Sims, Chapter 2, this volume). Intersecting formatives are independent of one another in their paradigmatic patterns, and most of these patterns are not consistently applied to all verb stems, making exponence highly unpredictable. This also means that the formatives are generally not in biunique relations with inflectional categories. Section 3.4 describes the paradigms as documented in the 1970s (Walsh 1976; Street 1987), as well as changes to the paradigms observed in our work with a new generation of speakers since 2010. In section 3.5 we compare the observed changes with the types of changes predicted by a model of complexity limitation in large lexical classes (Ackerman \& Malouf 2015), showing that none of the observed changes match the model. In section 3.6 we focus on two of the observed changes in particular, arguing that they diverge from the complexitylimitation mechanism because of incremental demorphologization, a process that is both analogical and destructive of existing analogies. In section 3.7 we summarize our findings.

\subsection{Complexity in lexically specified allomorphy}

There are several distinct dimensions of morphology that can be treated as forms of linguistic complexity (Kusters 2003, 2008; Anderson 2015a), but in this chapter we focus solely on (lexically specified) inflectional allomorphy. For example, in the Australian language Warlpiri verbs are suffixed with one of four lexically specified past tense allomorphs, $-c a,-\eta u,-\eta u,-n u$ (Hale 1969; Nash 1980: 40). Where lexemes share the same allomorph selection in all their forms, the shared paradigms are usually referred to as 'inflection classes'. Inflectional allomorphy of this type can be seen as prototypical morphological complexity, since it directly reduces form:meaning transparency (Aronoff 1998). 
The type of complexity instantiated by inflectional allomorphy can be conceptualized in terms of degrees of predictability in allomorph selection. For example, in a language where almost all verbs take -ak 1sG.PRES, and just a handful instead take -iq 1sG.PRES, the exponence is mostly predictable; only a small degree of complexity is involved. But in a language with several lexically-conditioned allomorphs, all more or less likely, there is low predictability, or high complexity. The larger the inflectional paradigm involved, the more that this problem of prediction becomes a real one for speakers of the language (or indeed linguists attempting to accurately document the lexicon and morphology), because where large paradigms are involved there is a more frequent and persistent requirement to produce previously unencountered forms (Bonami \& Beniamine 2016; Blevins et al. 2017). Degrees of inflectional predictability can be formalized and quantified using entropy, the weighted average of the log probabilities of all possible outcomes (Shannon 1948). Entropy can be taken as a measure of the unpredictability of a set of possible outcomes. The application of entropy as a measure of paradigmatic implicational structure was proposed by Ackerman et al. (2009).

Work on predictability of allomorphy has proceeded from the insight that the inflection of a lexeme is not predicted in an informational vacuum, but rather is a problem of predicting unknown inflectional forms, given one or more forms of the lexeme that have already been encountered. This has been labelled the 'Paradigm Cell Filling Problem' (Ackerman et al. 2009; Stump \& Finkel 2013; Bonami \& Beniamine 2016; Sims \& Parker 2016). The paradigmatic structure of inflection is thus crucial: typically, we expect that paradigmatic patterns are shared by lexemes in a language, with those lexemes that share a paradigm belonging to a common inflectional class. The known inflectional forms of a lexeme narrow the possibilities of which class the lexeme might belong to, thus reducing unpredictability of other forms. For example, the past tense suffix allomorphs mentioned above for Warlpiri can usually be predicted based on other inflectional forms. All verbs with imperative in - $n t a$ take the past allomorph - $n u$, licensing an inference from known form jinta 'scold.IMP' to the predicted form jinu 'scold.PsT' (Nash 1980, p. 40). However there are other instances where allomorphy for a particular tense/aspect/ mood (TAM) category does not uniquely identify an inflection class, leaving some unpredictability in the allomorphy of other forms. Table 3.1 shows the TAM

Table 3.1. Warlpiri verb inflection classes (Hale 1969; Nash 1980: 40)

\begin{tabular}{|c|c|c|c|c|c|}
\hline INFL CLASS & NON-PAST & PAST & IMPERATIVE & IMM. FUTURE & PRESENTATIONAL \\
\hline I & $-\mathrm{mi}$ & $-\mathrm{ca}$ & $-\mathrm{ja} \sim-\mathrm{ka}$ & $-j u$ & - na \\
\hline II & $-n \mathrm{i} \sim-n \mathrm{i}$ & $-\eta \mathrm{u}$ & $-\mathrm{ka}$ & $-\mathrm{ku}$ & -nipa \\
\hline III & - ni & $-n u$ & $-n k a$ & $-n k u$ & -naja \\
\hline IV & $-\eta \mathrm{i} \sim-n \mathrm{i}$ & $-\eta \mathrm{u}$ & - na & $-\mathrm{lku}$ & -nina \\
\hline V & $-n i$ & $-n u$ & -nta & $-n k u$ & -napa \\
\hline
\end{tabular}


allomorphs for all Warlpiri inflection classes. The syncretism between some classes for some tense categories makes these inflectional forms less than fully predictive of other inflectional forms of the same lexeme. For example, knowing that the presentational form is in -nina narrows the range of possible imperative allomorphs, but does not help us to decide between the two possibilities - $k a$, $-n a$. Residual uncertainty in predicting an inflectional form, given knowledge of other forms of the same lexeme, has been labelled integrative complexity (Ackerman \& Malouf 2013).

Integrative complexity meets several of the desiderata enumerated in Arkadiev \& Gardani's Introduction to this volume (Chapter 1). First, it is quantifiable and can be used to compare typologically diverse languages. Second, its conceptualization in terms of speaker inferences from known to unknown forms gives it a clear basis in psycholinguistic processing. Finally, whereas enumerative complexities lean heavily on the distinction between morphology and syntax, integrative complexity is relatively independent of this issue. Lexical selection of allomorphs generally occurs within units that are identified as words, but if a similar phenomenon occurred in phrase-like structures (e.g., periphrastic inflections with allomorphy on the auxiliary), this would have no real effect on the modelling of integrative complexity in the paradigm.

\subsection{Complexity, predictability, and language change}

In this chapter, we focus on the effects that language change may have on inflectional predictability. It has been shown that inflection class structure may persist in a language over long time periods (e.g., Maiden 2005; Gardani 2013), but even if it may in some instances be relatively stable, it is of course not completely static. The inflectional allomorphs selected by lexemes exhibit synchronic variation, with fluctuating variation rates over time leading to language change (Weinreich et al. 1968). The long-term patterns of changing allomorph selection have been studied in historically documented languages such as Latin (Gardani 2013: 201-28) and English (Jespersen 1949; Bybee \& Moder 1983). An interesting question is whether the direction of such change reflects limits on overall complexity and, conversely, what mechanisms lead to an increase in complexity.

There must be some upper limit of unpredictability at which inflectional systems remain learnable. If allomorphic distributions were too unpredictable, their prospects of being stably transmitted from one generation to the next would become rather slim. The obvious way to reduce unpredictability is to replace improbable allomorphs with more probable ones. We have little idea of how much unpredictability is too much, though crosslinguistic studies by Ackerman \& Malouf $(2013$, 2015) and Stump \& Finkel (2013) have documented the range of unpredictability found in genetically and typologically diverse samples. 
Ackerman \& Malouf (2013) compare synchronic inflectional systems in ten languages, showing that in all cases the average conditional entropy of one inflectional form of a lexeme, given knowledge of one other form, is between zero and 1.1 bits, the latter being approximately equivalent to a choice between two equally likely outcomes. Moreover, the languages in the sample that have the most allomorphs, and therefore risk the greatest unpredictability, are also the languages that make the most use of paradigmatic structure to mitigate unpredictability (Ackerman \& Malouf 2013: 443). In other words, paradigmatic structure of the type illustrated for Warlpiri above exhibits a strong crosslinguistic tendency to maintain a reasonable level of predictability for unknown inflectional forms. While Ackerman \& Malouf (2013) do not propose a specific numeric limit for how much integrative complexity learners can deal with, their study provides a principled method of quantification, and an initial sample of measurements, against which apparently complex languages such as Murrinhpatha can be compared.

A simulation of how language change might reduce unpredictability (Ackerman \& Malouf 2015) provides a useful model for considering the mechanism of analogical extension. Ackerman \& Malouf (2015) model diachronic change in an inflectional system based on the principle that, given a known inflectional form of a lexeme, and the requirement to predict an unknown form of the same lexeme, a speaker identifies lexemes that share allomorphs with the known form. Change proceeds by revising paradigm-internal relations to match the same morphosyntactic relations in other paradigms. We will henceforth use the terms 'source form' for the known form, 'target form' for the unknown form, 'comparable lexemes' for other lexemes that share allomorphy with the source form, and 'comparable source, comparable target' for the comparable forms that correspond in morphosyntactic category with the source and target forms respectively. Given the array of comparable lexemes, the speaker establishes which allomorph occurs most frequently among the comparable targets, and predicts this to be the allomorph for the target form. Predictions of this type are taken as a model for language change, because in the next iteration of the simulation, it is the predicted form that is now taken as the allomorph for the target cell, rather than the previous incumbent form. This is a hyperactive model of change, where overgeneralization errors go uncorrected. The model is not specific to either child acquisition or adult usage, which in any case may not be a sharp distinction in large inflectional systems, where some inflected forms must be guessed by speakers even after many millions of words of input (Blevins et al. 2017).

In Figure 3.1 we show the process of analogical induction, and replacement of the target form with a predicted form. A, B, etc., represent lexemes, with inflectional categories $A_{i}, A_{i i}, B_{i}, B_{i i}$, etc., while $x$, y represent exponence candidates. $A_{i}$ is the source form and $\mathrm{A}_{\mathrm{ii}}$ is the target form. $\mathrm{B}, \mathrm{C}, \mathrm{D}$ are comparable lexemes (sharing exponence with source form), while E, F are disregarded since they do 


$\begin{array}{|lll|} & \mathrm{A}_{\mathrm{ii}}=\text { unknown } & \\ \mathrm{A}_{\mathrm{i}}=\mathrm{x}_{1} & \text { compare } \rightarrow & \mathrm{B}_{\mathrm{i}}=\mathrm{x}_{1}, \mathrm{C}_{\mathrm{i}}=\mathrm{x}_{1}, \mathrm{D}_{\mathrm{i}}=\mathrm{x}_{1}, \mathrm{E}_{\mathrm{i}}=\mathrm{x}_{2}, \mathrm{~F}_{\mathrm{i}}=\mathrm{x}_{2} \\ & & \boldsymbol{\downarrow} \text { relate } \\ & & \mathrm{B}_{\mathrm{ii}}=\mathrm{y}_{1}, \mathrm{C}_{\mathrm{ii}}=\mathrm{y}_{2}, \mathrm{D}_{\mathrm{ii}}=\mathrm{y}_{2}\end{array}$

Figure 3.1. Ackerman \& Malouf (2015) mechanism for predicting unknown inflectional forms

not share exponence with the source form. The comparable lexemes analogically present both $\mathrm{y}_{1}$ and $\mathrm{y}_{2}$ as exponence candidates for the target form, but $\mathrm{y}_{2}$ wins out because it occurs more frequently in this distribution. If $\mathrm{A}_{\mathrm{ii}}$ is used as a source form or comparable lexeme form in a subsequent iteration, it will have the exponence $\mathrm{y}_{2}$.

Ackerman \& Malouf (2015) computationally simulate this model of inflectional change based on a 'highly unrealistic language' in which allomorphy is almost completely unpredictable in the initial state. The simulation language has a hundred lexemes, each of which inflects for eight morphosyntactic categories, giving a total of 800 forms in the system. Each morphosyntactic category has three allomorphs, which are randomly assigned to each lexeme. Thus there are $3^{8}=6,561$ possible inflectional paradigms, so that most of the hundred lexemes have an idiosyncratic paradigm, that is, not shared with any other lexeme. In this initial state, there are no inflectional classes. As the simulation iterates, replacement of unknown allomorphs with the most predictable allomorph leads to massive convergence of lexemes towards shared inflectional paradigms. The simulation ends when allomorphy stabilizes (i.e., the unknown form already is the most predictable form) for twenty-five consecutive iterations. Given hundreds of trials of the simulation, in a large proportion of simulations (no exact figure is given), all lexemes converge on a single set of allomorphs (i.e., no allomorphy), creating a single inflectional paradigm. In the remaining simulations, lexemes converge on between two and eighty-eight inflectional classes, the median number being twelve (Ackerman \& Malouf 2015: 8).

In terms of inflectional predictability, the initial random distribution of allomorphs $\left[\mathrm{x}_{1}, \mathrm{x}_{2}, \mathrm{x}_{3}\right]$ for each inflected form means that knowledge of other inflected forms does not offer any reduction to uncertainty (except by occasional accident of the distribution), and conditional entropy is therefore only marginally less than unconditional entropy, that is, $H(\mathrm{a}, \mathrm{b}, \mathrm{c})=1.58$ bits. But the replacement by most predictable allomorph mechanism in the simulated language change reduces this entropy to 0 bits in the instances where all lexemes converge on a single paradigm, and an average of 0.64 bits in the instances where the simulation converges on a set of inflectional classes (Ackerman \& Malouf 2015: 9). The average conditional entropy found in these simulated inflectional systems sits neatly within the range of 
$0-1.1$ bits found in the study of natural languages (Ackerman \& Malouf 2013). This provides support for the notion that the model's simplification mechanism may have something in common with mechanisms deployed in natural language.

One issue that has been insufficiently addressed in work on integrative complexity is the question of open versus closed lexical classes. The Ackerman \& Malouf (2015) simulation works with a set of a hundred lexemes, that is to say a finite set, and therefore a closed class. The basic formulation of the Paradigm Cell Filling Problem (PCFP; Ackerman et al. 2009) presumes that unknown inflectional forms must be predicted by a speaker, but also that the correct inflectional exponence is in some way defined-perhaps by a dictionary, or a more erudite speaker. Now, if we take 'open class' to mean a lexical class to which entirely new words can be added, then there must be a point at which inflectional forms of these words are not pre-defined, and there is no correct or incorrect selection of exponence. In other words, for truly open-class lexemes, the PCFP is undefined. In the next section, we will see that Murrinhpatha classifier stems are a closed class, with rather fewer members than may be intended in the original PCFP formulation. However, we argue that the model is still relevant, as Murrinhpatha speakers are not born with complete knowledge of the classifier stem paradigms, and must therefore use predictive mechanisms to extrapolate from known to unknown forms.

\subsection{Unpredictable exponence in Murrinhpatha classifier stems}

Murrinhpatha is a polysynthetic language with complex verbal structures including agreement morphology, nominal incorporation, adverbial modifiers, and complex predicates (Nordlinger 2017). Verbs are built on a finite stem element known as a 'classifier stem', ${ }^{3}$ which may either form a complete verb on its own or form the basis for a complex predicate. Classifier stems encode predicate semantics, subject person and number, and tense/aspect/mood marking. All Murrinhpatha verbs require a classifier stem in first position (bolded in the examples below). There are thirty-nine classifiers, each of which appears in forty-two inflected forms, thus giving a total of 1,638 inflected forms. Eleven of the thirty-nine classifiers can form a verb on their own (1), the remaining twentyeight are only ever found in combination with a second, uninflecting stem element later in the verbal word (underlined in the examples below) with which they jointly determine the predicate semantics (2)-(5). The only allomorphy in the verb is in the classifier stem element-all other elements have a single exponence, subject only to phonologically motivated alternations. For more discussion of the

\footnotetext{
3 In other work these have been called 'auxiliaries' (Walsh 1976), 'classifier-subject pronominals' (Nordlinger 2011), and 'finite verbs' (Mansfield 2016).
} 
details of the system the reader is referred to Blythe (2009), Nordlinger (2011, 2015), and Mansfield $(2016,2019)$ among others. ${ }^{4}$

\section{(1) wuran}

3sGS.Go(6).NFUT

'She goes.'

(2) munam-pal

3sGS.COERCE(11).NFUT-break

'She broke it off.'

(3) pam-ninta-nu-ma- tatal

3SGS.SLASH:RR(24).NFUT-DU.F-RR-APPL-tear

'They (two female non-siblings) tore the (cloth) from each other.' (RN-20070531-002:011)

(4) pirim-ninta-nu-bu-wuj-wada-ya

3SGS.STAND(3).NFUT-DU.M-RR-thigh-put.into-NOW-DM

'They put them in their pockets.' (JB 43JBc743652_747130)

(5) puddan-wunku-lal-dejida-nime=pumpan-ka

3DUS.SHOve(29).NFUT-3PCO-drop-in.turn-PC.F=3DUS.GO(6).NFUT-DU

'They (dual, sibling) are dropping them (paucal, female, non-sibling) off, one after the other, as they go along.' (Blythe 2009: 134)

For most classifier stems the exponence pattern making up the paradigm of fortytwo inflected forms is unique to that stem. Thus the concept of inflectional classes' - a set of exponence paradigms shared by many lexemes-is not directly applicable to Murrinhpatha. (1)-(5) show classifier stems as unsegmented wholes, and this has been the representation used in most work on Murrinhpatha. However there are semi-regular subcomponents evident in these stems, and it is these that we treat as exponents of inflectional categories. These are not productive morphs that are applicable to new lexemes in an open class, however they do constitute morphology in the sense of form:meaning associations between systematically related forms (Anderson 2015b).

\footnotetext{
${ }^{4}$ In the Appendix we have provided paradigms for five classifier stems, to exemplify the complexity amongst them. Previous descriptions of the Murrinhpatha verbal system (e.g., Blythe et al. 2007; Nordlinger 2011,2015) have tended to treat these classifier stem paradigms as consisting of synchronically unanalysable portmanteau forms, due to the substantial amounts of unpredictability and suppletion within the paradigms. The full set of thirty-nine paradigms as analysed in this chapter is available at http://langwidj.org/Murrinhpatha-inflection.
} 
We assume that Murrinhpatha speakers to some extent store classifier stems as whole forms, rather than composing them online from the elements of exponence (cf. Mithun, Chapter 12, this volume). However this does not mean that inflectional exponence has no role in acquisition or processing. We do not know how much input is required for a Murrinhpatha speaker to encounter all 1,638 forms enough times that they can all be memorized, but the available evidence on corpus distribution of inflected forms suggests that many years of input are required to offer complete coverage of large paradigms (Blevins et al. 2017). As with other inflectional systems, when Murrinhpatha speakers parse or produce forms that they have not yet encountered, the recurrent patterns of exponence offer predictive clues. Indeed, the evidence of analogical change presented in this chapter shows that classifier stem forms are not acquired and stored as isolated forms: speakers draw on the exponence of one classifier to produce the exponence of another. Research on child acquisition of Murrinhpatha verb inflection also shows that children make occasional errors in allomorphy selection, revealing morphological structure in the acquisition of classifier stems (Forshaw 2016). Therefore, both the PCFP (Ackerman et al. 2009) and the Ackerman \& Malouf (2015) simplification mechanism are relevant to Murrinhpatha. The fact that Murrinhpatha classifier stems constitute a closed class does not disqualify them from applicability of these models, since, as we observed above, the PCFP is only strictly defined for a closed class.

\subsubsection{Intersecting formatives and unpredictable allomorphy}

Inflectional allomorphy in Murrinhpatha classifier stem paradigms is both highly complex and typologically unusual, meaning that a detailed exposition is beyond the scope of this chapter. ${ }^{5}$ Murrinhpatha's thirty-nine classifiers each appear in forty-two inflected forms (and never in non-finite form). The 'inner stems' upon which these forms are built are highly mutable, creating much of the complexity in the system (cf. Parker \& Sims, Chapter 2, this volume). Table 3.2 illustrates some sample classifier forms, ${ }^{6}$ representing two classifiers (la 'WIPE(26)', ma 'DO(34)') that have fairly clear phonological stems, one classifier ( $r u$ ' $\mathrm{GO}(6)$ ') that has a highly mutable stem, and one classifier ( $i$ 'sIT(1)') that has a vowel-only stem,

${ }^{5}$ Fuller description is available in Mansfield (2016, 2019), drawing on earlier partial analyses (Walsh 1976: 224; Green 2003; Forshaw 2016: 37). As shown in the examples above, there is also further inflectional morphology in the verb that is not part of the classifier stem paradigms, and can be applied equally to verbs based on any classifier stem (Nordlinger 2015,2017). This morphology has no bearing on the issues discussed in this chapter and will therefore not feature in our remaining discussion.

6 The full paradigms are provided in the Appendix. 
Table 3.2. Examples of inflected classifier forms

\begin{tabular}{llll}
\hline & 3SG.IRR & 3sG.NFUT & 3PL.PST \\
\hline la 'WIPE(26)' & kila & dilam & pilla \\
ma 'DO(34)' & ma & mam & pume \\
cu 'GO(6)' & kuru & wuran & puni \\
i 'sIT(1)' & $\mathrm{ki}$ & dim & pirini \\
\hline
\end{tabular}

which only surfaces phonologically when it syllabifies with a consonantal stem alternation, and otherwise results in a phonologically empty stem. ${ }^{7}$

The challenge for segmentation and analysis of classifier forms lies in the fact that each form combines several independent dimensions of allomorphy. Each inflected classifier form selects a prefix consonant allomorph, an orthogonally distributed prefix vowel allomorph, and an orthogonally distributed suffix allomorph (any of which can be zero). We label this combination of orthogonal allomorphs inflection by intersecting formatives (Mansfield 2016). Intersecting formatives appear to be a recurrent feature of highly complex verbal inflection systems, such as Mazatec (Ackerman \& Malouf 2013), Greek (Sims 2015: 143ff), Saami (Feist 2015: 140ff), and Seri (Baerman 2016). Intersecting inflectional formatives are given an explicit formulation in Network Morphology, where they are represented as multiple inheritance of inflection class nodes (Brown \& Hippisley 2012: 71ff), and there is further discussion of the phenomenon with respect to complexity in Parker \& Sims (Chapter 2, this volume), where intersectional inflection is labelled 'paradigmatic layers'. Intersectional inflection often combines concatenative and supra-segmental morphology, and this is also the case in the Murrinhpatha verb forms.

The Murrinhpatha classifier stem is built on a phonologically minimal inner stem' of the shape $(\mathrm{C})(\mathrm{C}) \mathrm{V}$, which alternates in three orthogonal dimensions: stem consonant mutation, vowel height, and vowel frontness. Each inflected form of a classifier stem is therefore determined by six dimensions of intersecting allomorphy: PrefC, PrefV, StemC, StemVH, StemVF, and Suffix. Table 3.3 illustrates the intersecting formative analysis of the forms shown above in Table 3.2. Formatives exhibit 'semi-regularities' that appear in some but not all exponents of a morphosyntactic cell, for example, PrefC $k$ - in 3sg.IRR, Suffix $-m$ in 3sg.NFuT. Other (semi-)regularities attach to particular classifier stems, for example PrefV $i$ - in

\footnotetext{
7 The description of 'vowel-only stems' is somewhat different from Mansfield (2016), where they are simply labelled 'phonologically empty stems'. The analysis there nonetheless depends on underlying 'theme vowels' in such stems, though this is not explicitly discussed. An alternative analysis would propose a zero theme vowel, to avoid the use of unrealized underlying vowels. We have experimented with calculation of Murrinhpatha integrative complexity using both analyses, and found that the difference is very small $(<1 \%)$. The unrealized vowel alternative produces slightly lower complexity measurements, and we therefore select this option to keep our complexity measurements conservative.
} 
Table 3.3. Examples of classifier forms and their formative analyses

\begin{tabular}{|c|c|c|c|}
\hline & 3SG.IRR & 3SG.NFUT & 3PL.PST \\
\hline & $\begin{array}{l}\text { FORM } \\
\text { PREF.C - PREF.V - }\end{array}$ & $\mathrm{M}[\mathrm{C}, \mathrm{VH}, \mathrm{VF}]-$ SUFFIX & \\
\hline $\begin{array}{l}\text { la 'WIPE(26)' } \\
\text { ma 'Do(34)' } \\
\text { ru 'GO(6)' } \\
\text { i 'SIT(1)' }\end{array}$ & $\begin{array}{l}\text { kila } \\
\text { k-i-la[DEF]- } \varnothing \\
\text { ma } \\
\varnothing-u-m a[D E F]-\varnothing^{*} \\
\text { kuru } \\
\text { k-u-ru[DEF]- } \varnothing \\
\text { ki } \\
\text { k-i- } \varnothing[D E F]-\varnothing\end{array}$ & $\begin{array}{l}\text { dilam } \\
\text { d-i-la[DEF]-m } \\
\text { mam } \\
\varnothing \text {-u-ma[DEF]-m } \\
\text { wuran } \\
\text { w-u-ra[vH:LOw]-n } \\
\text { dim } \\
\text { d-i- } \varnothing[D E F]-m\end{array}$ & $\begin{array}{l}\text { pilla } \\
\text { p-i-lla[C:GEM]- } \varnothing \\
\text { pume } \\
\text { p-u-me[Vf:Front]- } \varnothing \\
\text { puni } \\
\text { p-u- } \varnothing[\text { c:WEAK]-ni } \\
\text { pirini } \\
\text { p-i-ri[C:RR]-ni }\end{array}$ \\
\hline
\end{tabular}

Notes: * PrefV, like the stem vowel, does not surface unless it can syllabify with an onset consonant. Thus we can analyse a PrefV $u$ - formative in $ø$ - $u$-ma-m 3sG.Do(34).NFUT, in keeping with this classifier's overall paradigmatic pattern, though the surface form is mam.

$\mathrm{DEF}=$ default; $\mathrm{GEM}=$ geminate; $\mathrm{RR}=\boldsymbol{\rho}$-alternation.

WIPE(26) and SIT(1), but PrefV $u$ - in Do(34) and Go(6). Importantly, these patterns are often orthogonal-for example, the PrefV selection is independent of the PrefC selection in 3SG.IRR.

As shown in the full paradigm examples in the Appendix, the complete morphosyntactic paradigm of a classifier stem consists of forty-two inflectional forms. Subjects are distinguished for $1 / 2 / 3$ person, cross-cutting a three-way sG/DU/PL number distinction (although DU/PL is consistently collapsed in NFUT tense, and in all tenses for some paradigms). ${ }^{8}$ There is also a $1+2$ 'we inclusive' person category, which has no number distinctions. These are the core number/person categories of Murrinhpatha, but more specific subcategories can be encoded using various predictable suffixes not discussed here (Nordlinger 2015). There are four basic tense/ modality categories (henceforth 'tenses'): non-future (NFUT), irrealis (IRR), past (PST), and past irrealis (PSTIRR), as well as 'subtense' distinctions between NFUT vs presentational (PRSL), and IRR vs future indicative (FUT), which apply only to third-person forms. Again, these core categories can be further specified by predictable suffixes encoding tense, modality, and aspect (Nordlinger \& Caudal 2012). Table 3.4 illustrates a complete paradigm of inflected forms for one of the more regular classifiers, na 'HEAT(27)', with both surface forms and intersecting formative analysis.

Some formatives in some cells have a consistent form (i.e., no allomorphy), such as PrefC $p$ - in 3PL.PST. More typical is a selection between a handful of formative allomorphs, for example Suffix - $m,-n$, -yam, -yan in NFUT, or PrefV $a-, e-, i, u$ - for all cells. A particularly wide selection of allomorphs is PrefC $p^{-}, w^{-}, d_{-}, n_{-}^{-}, j^{-}, k_{-}^{-}$,

8 The category here labelled DU is used for both dual and paucal referents; it is labelled PAUCAL (PC) in Mansfield (2016) and DAUCAL in Blythe (2009). 


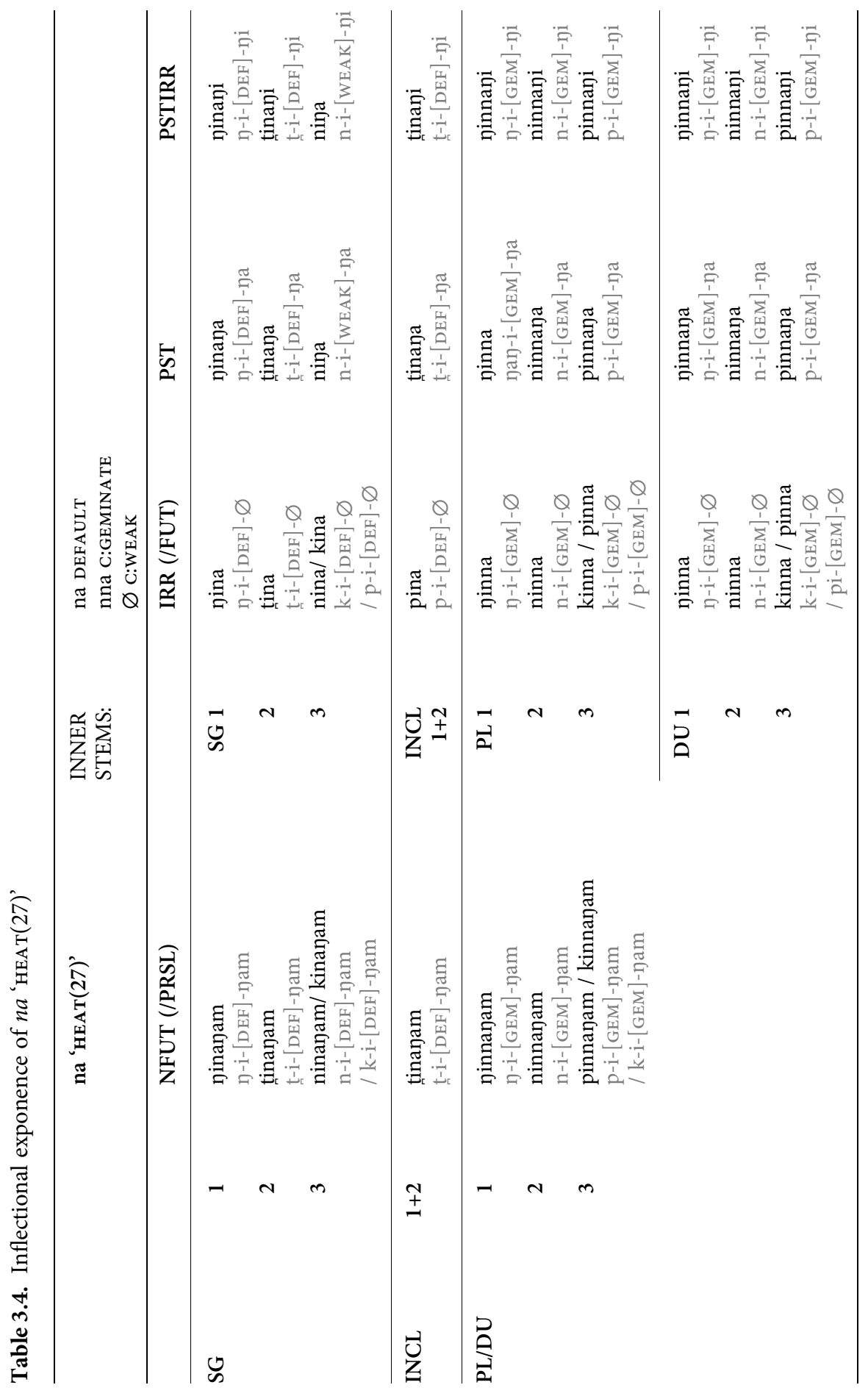


$\emptyset$ - 3sG.NFUT, and StemC allomorphy also has a large selection of allomorphs, once we take into account various suppletive (i.e., altogether unpatterned) consonant alternations.

From the point of view of integrative complexity, that is, the predictability of an inflected form given knowledge of some other form, the formatives individually have an intermediate degree of predictability. In certain dimensions there is very high predictability: for example, if one NFUT form takes Suffix -yam, there is a very high likelihood (though not quite categorical) that any other NFUT form of the same verb will take Suffix -yam. This is illustrated in the consistent tense patterning of Suffix allomorphs in Table 3.4. Among cells that have the same tense and number categories but differ for $1 / 2 / 3$ person, the only difference of exponence is usually PrefC; these triplets of cells are therefore tightly integrated in terms of implicational structure. However, when we consider the implicative relationship between cells from different tenses, we find that, say, knowing NFUT -yam provides little information about the Suffix allomorph for PST cells. Allomorph selection across tenses is strongly orthogonal. Other formatives have generally high degrees of integrative complexity, that is to say, inconsistent paradigmatic patterning. This is especially true of the stem formatives StemC, StemVH, and StemVF, and also to some extent of PrefV.

The problem of predicting an unknown inflected form of a Murrinhpatha classifier stem therefore involves predicting allomorph selection for six intersecting formatives, based on knowledge of such an intersection for some other form of the classifier stem. Some formatives provide good chances of correct prediction, while others are rather less helpful. This situation is not as extreme as the completely random paradigmatic distribution of allomorphs in Ackerman \& Malouf (2015)'s 'unrealistic language', though the presence of six different dimensions of allomorphy in Murrinhpatha nonetheless leads to a high degree of complexity, since the unpredictability of the allomorphs is compounded.

Because Murrinhpatha classifier stems often have idiosyncratic exponents, that is, allomorphs not shared by any other classifier stem, the entropy calculations used in Ackerman \& Malouf (2013) are not directly applicable. The latter's allomorphic entropy method assumes that all possible exponents have been encountered in other lexemes, so that allomorphy prediction involves a distribution of possible outcomes. But in a system with idiosyncratic exponents, the unknown target exponent may be one that has not previously been encountered (cf. Dahl, Chapter 13, this volume). The speaker's challenge is not one of entropy in the distribution of previous observations, but of attempting to predict an outcome that may or may not match any previous observation. Thus the mathematical analysis calculates chance of correct prediction (including zero chance for a previously unencountered paradigmatic relation), rather than degrees of entropy. Nonetheless, we can make a notional comparison of Murrinhpatha with the crosslinguistic findings on entropy in Ackerman \& Malouf (2013). The latter 
finds average conditional entropy between 0 and 1.1 bits, and 1 bit of entropy equates to a randomized prediction having 50\% chance of matching the outcome. Mansfield (2016) calculates that the average chance of correct prediction from one Murrinhpatha classifier stem form to another is $43 \%$, comparable to 1.22 bits of entropy. ${ }^{9}$ This is slightly outside the range of the Ackerman \& Malouf sample, suggesting that Murrinhpatha's closed-class classifier stems have an integrative complexity at the upper end of the scale found for open-class systems in other languages. As far as we know, the only language that has been analysed as having clearly higher integrative complexity is Seri (isolate, Mexico), which has almost 2 bits average conditional entropy (Baerman 2016).

\subsubsection{Variation and change}

With 39 x $42=1,638$ inflectional cells to be learnt, and implicational relations proving only moderately helpful in deducing unknown forms, it would be surprising if all Murrinhpatha speakers selected the same allomorphs all the time. The presence of allomorphic variation in Murrinhpatha classifier stem forms has previously been explored only to the extent that some paradigm cells are documented with two or more variants, for example nu.qa na 3sGS.FEET(7).PST (Street 1987: 84). The 1,638 cells of the full classifier stem paradigms have been documented based on a limited set of spontaneous speech data, with gaps filled by systematic elicitation of paradigms by multiple researchers over a number of years of descriptive work. These collective findings are collated as Blythe et al. (2007), and since then have been further revised and reanalysed in Mansfield (2019) although many questions still remain. Understanding the extent of allomorphic variation, the proportion in which variants are used, and any conditioning factors on the variation requires much more data. Investigation of such variation in Murrinhpatha is still a work in progress, but after forty years of intermittent research on this language, there are now some inflectional variables for which we have enough corpus tokens to begin proposing patterns of variation and implicit diachronic change.

For this study we have identified seven inflected forms with attested variation. These are the complete set of forms that fulfil the following criteria:

(a) Variation attested in the corpora of adult speech recorded by Blythe, Mansfield, Nordlinger, Street, \& Walsh; ${ }^{10}$

(b) Allomorphic variants are attested with multiple corpus tokens for each variant;

9 That is, $\log _{2}(1 / 0.43)=1.22$.

${ }^{10}$ Much of this corpus material is stored in public archives at the Australian Institute of Aboriginal and Torres Strait Islander Studies (Walsh), the Max Planck Institute Language Archive (Blythe), and PARADISEC (Mansfield, Nordlinger). 
(c) The variation is morphological, rather than purely phonological. For example, pujemam pijemam 3PLS.Do(34).NFUT is purely phonological variation based on assimilation of the vowel to the following glide, and is therefore not an instance of lexically specified allomorphy.

None of the seven variables thus identified have enough corpus tokens to support a rigorous variationist analysis. Nor is there sufficient data to permit differentiation between contextual factors such as phrasal context, speech style, speaker gender, etc. Rather, in this study we focus purely on the distribution of variants among speakers born in the first half of the twentieth century ('older speakers') versus those born in the second half ('younger speakers'). This method allows us to detect proportions suggestive of change in progress in inflectional variants, and thereby to search for signs of the Ackerman \& Malouf (2015) simplification mechanism in effect. In fact, for all seven of the variables, there is a striking difference between variant distributions among older and younger groups, with the younger moving strongly towards the variant not attested in earlier documentation. ${ }^{11}$ This is likely not an accident: the fact that these seven inflected forms were noted as variable is primarily because they stood out in Mansfield's fieldwork as conflicting with earlier grammatical descriptions of the language. On the other hand, though speakers showed clear awareness of social indexicality in phonological and lexical variation among the generations, they were unaware of the intergenerational variations in inflectional morphology (Mansfield 2014: 469ff).

It has often been observed that less frequent inflectional forms are more susceptible to analogical change in morphology, though frequent forms may also undergo such changes (e.g., Fertig 2000: 125). Since our method for identifying changes in Murrinhpatha depends on the salience of these changes in fieldwork, these can all be said to occur in fairly frequent forms. We presume that further analogical changes occur in less frequent forms, though we have not had the opportunity to observe these, and the corpus data drawn upon for this study does not permit robust estimates of inflectional form frequency.

Table 3.5 lists the seven observed variables, with variants preferred by older and younger speakers respectively according to the corpus evidence. Note that where regular triplets of $1 / 2 / 3$ person inflections are all involved, these are treated as a single variable in view of their tight mutual implications. Token numbers in parentheses indicate the number of tokens found for the older:newer variants among that speaker group. For example, for 1sGS.DO(34).PST, older speakers were found to have five tokens of me and one token of yeme,

\footnotetext{
${ }^{11}$ Some of the sources for older speakers are written (e.g., Bible; Street 1987) and do not have accompanying audio sources. It is possible that these sources underreport use of innovative variants, by correcting them to what may have been seen as the 'correct' form. This may account for some of the strength of the swing in proportions from older to younger speaker groups.
} 
Table 3.5. Variably inflected classifier stem forms

\begin{tabular}{lll}
\hline Classifier, inflection & Older speakers (tokens) & $\begin{array}{l}\text { Younger speakers } \\
\text { (tokens) }\end{array}$ \\
\hline ma, 1SGS.DO(34).PST & me $(5: 1)$ & neme $(0: 9)$ \\
ma, 2SGS.DO(34).NFUT & nam $(7: 1)$ & tamam $(10: 13)$ \\
ma, PL.DO(34).NFUT & namam, namam, pamam (17:5) & nujemam etc (3:12) \\
fu, DU.GO(6).IRR & na, na, ka (3:0) & nu etc $(0: 3)$ \\
nu, DU.FEET(7).PST & nunna, nunna, punna (10:1) & nunne etc $(0: 10)$ \\
ra, 3PL.WATCH(28).NFUT & panan (4:0) & pirim $(1: 5)$ \\
ri, 3PL.WATCH: RR(36).NFUT & pim (2:0) & pirim $(0: 5)$ \\
\hline
\end{tabular}

while younger speakers were found to have zero tokens of me and nine of neme.

Interestingly, one of the few forms earlier documented as being variable, nu.qa na 3SG.FEET.PST (Street 1987: 84), showed only marginal variability in the corpus data. There are dozens of attestations for $n a$, and only one for nu.ja, suggesting that the latter variant was already on its way out when Street recorded it.

\subsection{Predictability of changes observed in Murrinhpatha}

In the last section we saw that Murrinhpatha classifier stems are a closed class in which the inflectional paradigms are large, and implicational relations are highly unpredictable. We also saw that allomorphy of exponence in this system is not static, but rather encompasses some variable forms, which show signs of change over the last couple of generations. Thus we are now in a position to investigate whether the changes observed in Murrinhpatha decrease or increase the complexity of the system. To test this, we ran the Ackerman \& Malouf (2015) simplification method (with adaptions as described above) on the relevant classifier forms, identifying the most predicted allomorphs. We show that the observed change does not replace an incumbent allomorph with the most predictable allomorph in any of the seven inflected forms. We then go on to consider a weaker form of the Ackerman \& Malouf (2015) simplification mechanism: when speakers replace an old allomorph with a new one, do they at least select one that is more predictable than the previous? We find that, on the contrary, most of the changes observed in Murrinhpatha select less predictable allomorphs, thus increasing the complexity of the system.

The Ackerman \& Malouf (2015) simplification mechanism was implemented for Murrinhpatha classifier inflections using intersecting formatives to draw independent analogies, since this method has been shown to provide the 
Table 3.6. Allomorphs selected by Ackerman \& Malouf (2015) simplification mechanism

\begin{tabular}{llll}
\hline Classifier, inflection & $\begin{array}{l}\text { Older } \\
\text { speakers }\end{array}$ & $\begin{array}{l}\text { Younger } \\
\text { speakers }\end{array}$ & $\begin{array}{l}\text { Ackerman \& Malouf (2015) } \\
\text { simplification }\end{array}$ \\
\hline ma, 1sG.DO(34).PST & me & neme & me \\
ma, 2sG.DO(34).NFUT & nam & tamam & nam \\
ma, PL.DO(34).NFUT & namam etc & nujemam etc & numam etc \\
ru, DU.GO(6).IRR & na etc & nu etc & nu.qu etc \\
nu, DU.FEET(7).PST & nunna etc & nunne etc & nunni etc \\
ra, 3PL.WATCH(28).NFUT & panan & pirim & pi.jam \\
ri, 3PL.WATCH:RR(36).NFUT & pim & pirim & pi.jim \\
\hline
\end{tabular}

greatest probability of correctly predicting allomorphy (Mansfield 2016). ${ }^{12}$ The implementation iterates through every inflected form of every Murrinhpatha classifier stem, treating each in turn as a target form requiring analogical prediction. The predictive mechanism takes each other inflected form of the classifier stem in turn as a source form, and for each identifies comparable classifier stems, from which candidate allomorphs for the target form are deduced. The probability of each candidate allomorph is the proportion of comparable classifier stems that imply that allomorph. The probability of candidates is aggregated across all source forms, revealing the overall most probable candidate. The most probable candidate allomorphs selected by the implementation for our variable inflected forms are illustrated in Table 3.6, along with the older and younger speakers' attested forms (see full paradigms in Appendix).

The results of the implementation do not in any instance match the innovative forms observed among younger speakers. However, in some instances the observed innovation, in comparison with the older form, does exhibit some of the formative allomorphs selected by the Ackerman \& Malouf (2015) simplification. For example in 1DU.Go(6).IRR, the older form is $y a$ and the simplification form is $\eta u . u$. The observed innovation $\eta u$ does exhibit the switch to PrefV $u$-, but maintains the weak stem grade of the older form, rather than the StemC [GEM] $\iota^{u}$ of the Ackerman \& Malouf (2015) simplification. ${ }^{13}$ Similarly, in 3PL.WATCH(28).NFUT the observed innovation takes on both the PrefV $i$ - allomorph, and the Suffix - $m$ of the Ackerman \& Malouf (2015) simplification, but does not take up the StemC [GEM] ta selected by the simplification, and also diverges from the

12 The implementation code is written in Python (Python Software Foundation n.d.), and takes as input the inflectional paradigm data format established for the Principle Parts Analyzer (Finkel \& Stump 2013). Both code and data are available online at http://langwidj.org/Murrinhpatha-inflection.

${ }^{13} \mathrm{rU}[\mathrm{DEF}] \rightarrow \downarrow u[\mathrm{GEM}]$ may not seem like an obvious case of gemination, but it follows from a $\rho \uparrow \rightarrow$ $\iota$ process observed in Murrinhpatha's sister language Ngan'gityemerri (Reid 1990) and their shared proto-language (Green 2003). In Murrinhpatha it is observable only in the classifier stem paradigms, where it fits with a broader gemination pattern. 
Table 3.7. Exponence probabilities of older and newer forms

\begin{tabular}{lll}
\hline Classifier, inflection & Older form (prob.) & Newer form (prob.) \\
\hline ma, 1sG.DO(34).PST & me $(.37)$ & neme $(.00)$ \\
ma, 2SG.DO(34).NFUT & nam $(.14)$ & tamam $(.09)$ \\
ma, PL.DO(34).NFUT & namam, namam, pamam $(.14)$ & nujemam etc $(.00)$ \\
ru, DU.GO(6).IRR & na, na, ka (.06) & nu etc $(.06)$ \\
nu, DU.FEET(7).PST & nunna, nunna, punna $(.06)$ & nunne etc $(.06)$ \\
ra, 3PL.WATCH(28).NFUT & panan $(.06)$ & pirim $(.06)$ \\
fi, 3PL.WATCH:RR(36).NFUT & pim $(.06)$ & pirim $(.12)$ \\
\hline
\end{tabular}

simplification by selecting StemVF [FRONT] (vowel frontness) and StemVH [HIGH] (vowel height) formatives. Finally, DU.FEET(7).PST takes up the StemVF [FRONT] alternation selected by the simplification, but maintains the StemVH [LOW] (vowel height) alternation of the older form, instead of selecting the StemVH [DEF] of the simplification.

Since some of the observed innovations take up subsets of the formative intersection selected by the adapted Ackerman \& Malouf (2015) simplification, which is the overall most probable exponence, we might wonder whether the observed innovations represent partial or incomplete moves towards Ackerman \& Malouf (2015) simplification. Do the observed innovations have greater probability of being predicted by analogy than the older forms they appear to be replacing? To this question, the answer is again negative, as illustrated in Table 3.7.

Table 3.7 illustrates that in six out of the seven instances, the innovative form has either lower probability of being predicted than the older form, or equal probability. Only one instance, the innovation in 3PL.WATCH:RR(36).NFUT, creates a more predictable exponent. Even though some of the innovated formatives match the Ackerman \& Malouf (2015) simplification, the selection of nonsimplified formatives undermines the predictability of the entire form. We must therefore conclude that the changes to inflectional allomorphy observed in Murrinhpatha data collected over forty years (or at least, apparent changes, suggested by different distribution of variants among older and younger speakers) increase the complexity of the system. Most of the changes replace more predictable allomorphs with less predictable ones.

\subsection{Demorphologization and deepening complexity}

Observed changes in Murrinhpatha increase the unpredictability of inflectional allomorphs because of breakdown in the structure of intersecting formatives. In this section we argue that this is a form of incremental demorphologization, where allomorphic proliferation is associated with the breakdown of segmentability. 
Demorphologization in this sense is a complexifying force running counter to the simplifying force of analogical levelling. Indeed, this demorphologization process appears to be the same phenomenon that has been underway for a much longer time period, leading to the unpredictability of implicational relations in the classifier paradigms. Blurring of constituent boundaries between the inner stems and affixal exponents in the classifier paradigms has produced the semiregularities of the inflectional system.

Ackerman \& Malouf (2015) propose that the requirement for inflectional allomorphs to be reasonably predictable, given knowledge of other forms of the same lexeme, is a 'strong evolutionary pressure in language' (Ackerman \& Malouf 2015: 7). They present their model for iteratively simplifying predictions as a demonstration of how predictability might be achieved, though they do not claim that this is the actual mechanism at work in the evolution of natural languages. ${ }^{14}$ The implementation of their mechanism for Murrinhpatha, compared to observed changes in the language, suggests that a simplification mechanism of this type is not in operation in the closed-class system of Murrinhpatha. But the broader point remains valid: inflectional changes do appear to reflect analogies drawn by speakers based on the paradigms of other lexemes. This point of view is supported because the innovated forms in Murrinhpatha copy phonological elements found in other classifier forms with which they share morphosyntactic characteristics, rather than being purely phonological changes. But rather than following a direct aggregation of probable allomorphs, there appear to be other predictive influences at work-interference in the system, which leads to an increase in integrative complexity.

Each of the innovations observed in Murrinhpatha has its own story, with potential sources of analogy detectable upon investigation of paradigmatically related forms. We here describe two of the innovations in particular, selected because they illustrate a means by which allomorphic complexity may be perpetuated, rather than reduced. ${ }^{15}$ As with all the observed changes, these are not the forms selected by the Ackerman \& Malouf (2015) simplification mechanism.

\footnotetext{
${ }^{14}$ In fact, their main argument focuses on the greater generality of their Low Conditional Entropy Conjecture (Ackerman \& Malouf 2013) as compared to the No Blur Principle (Carstairs-McCarthy 1994), which does not directly concern us here.

${ }_{15}$ The other changes observed are potentially explicable by more subtle departures from the Ackerman \& Malouf (2015) simplification mechanism-for example, by weighting of comparable classifier stems according to their respective entropies of prediction, with near-categorical predictors given extra weight (2SG.DO(34).NFUT), or by allowing prediction to be based on phonological relationships, including identity, rather than inflectional exponents (PL.DO(34).NFUT) (Bonami \& Beniamine 2016). DU.GO(6).IRR and.DU.FEET(7).PST seem to involve greater independence of formatives than has been previously proposed for the system (Mansfield 2016). Satisfactory analysis of any of these instances would require a separate study.
} 
(6)

\author{
1SG.DO(34).PST \\ Older form \\ $\varnothing$-a-me[FRONT]- $\varnothing$ \\ me
}

Ackerman \& Malouf (2015) simplified

$\varnothing$-a-me[FRONT]- $\varnothing$

me

\author{
Observed \\ n-e-me[FRONT]- $\varnothing$ \\ neme
}

In the case of (6), there are two observed deviations from Ackerman \& Malouf (2015), the first of which is the selection of PrefC $\eta$-instead of $\varnothing$-. Both $\eta$ - and $\varnothing$ are in fact candidates implied by comparable classifier stems for various source forms, with $\varnothing$ - selected because it has an aggregate 0.73 probability among all source forms, versus 0.27 for $y$-. It is easy to imagine that this outcome might be different, as in the observed innovation yeme, if there were some weighting in the influence of source forms and comparable classifier stems. However the second deviation from Ackerman \& Malouf (2015) involves the introduction of PrefV e-, and this is not even a candidate by analogy with comparable classifiers. Classifier stems that do have PrefV $e$ - are never selected as comparable, because none of the $m a$ 'DO(34)' source forms use this allomorph, as illustrated in Table 3.8. Rather, the competing candidates are $a-\sim u$-. Notice, however, that 1sG.DO(34).PST, like all DO(34).PST forms, has a StemVF [FRONT] alternation. It seems that rather than arising from analogical prediction of PrefV allomorphy, the form yeme applies vowel fronting beyond the morphological inner stem structure $m a \sim m e$ in which the pattern is more generally established. On this view, the predicted form is derived analogically from other forms, but the prediction of vowel fronting has been inherited upwards into a morphological unit larger than the inner stem. Such abrogation of the structural distinction between inner stem and prefix is perhaps not surprising, given the widespread lack of phonological transparency in Murrinhpatha classifier stems.

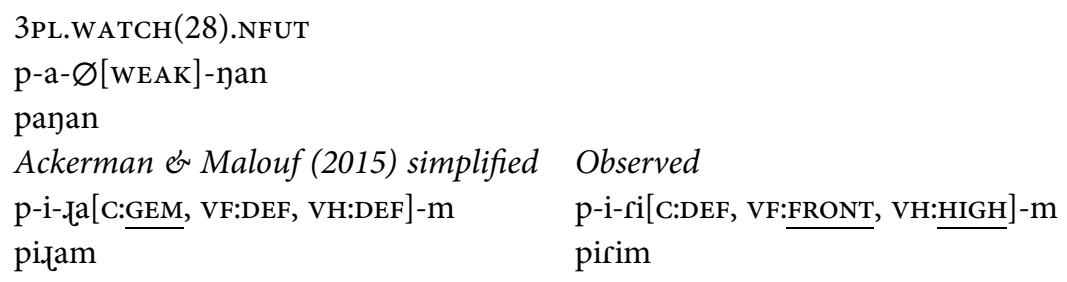

The case of (7) suggests more extensive breakdown of inner stem/affix structure in the predictive mechanism. Here the observed deviations from the Ackerman \& Malouf (2015) simplification again include a consonant formative that is an analogical candidate though not the aggregate strongest candidate, StemC [DEF] instead of StemC [GEM], which again could be accounted for in a system that includes some weighting of candidates. The other deviation is in the vowel 
Table 3.8. Classifier stem paradigm for $m a$ 'Do(34)'

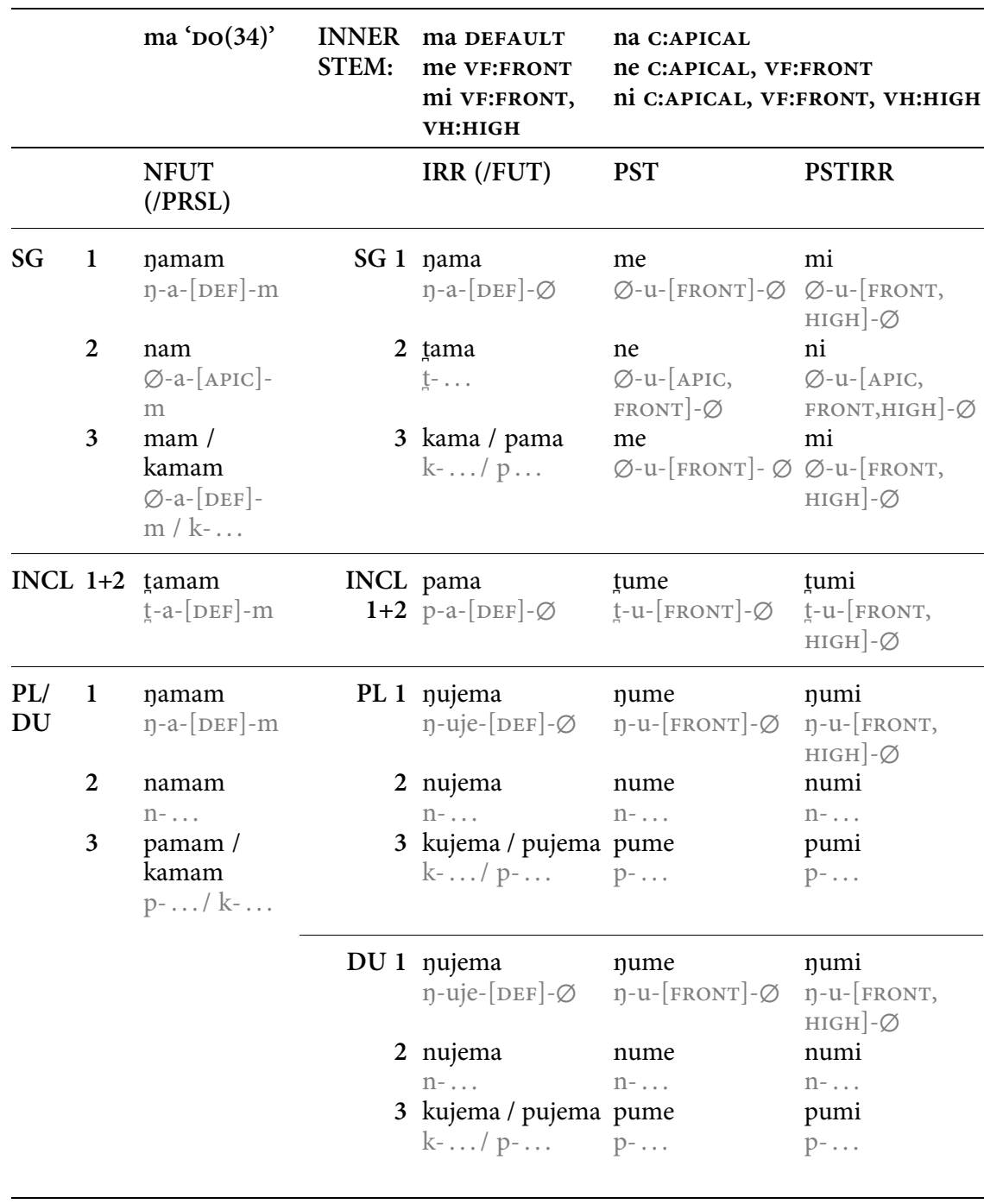

formatives StemVF [FRONT] and StemVH [HIGH], neither of which is predicted by formative analogies. None of the source forms use such stem vowel alternations (Table 3.9). Rather, the default inner stem vowel $a$ is overwhelmingly predicted, rather than the observed [FRONT, HIGH] alternation $i$. The most obvious explanation in this case is the existence of a 3PL.NFUT form pirim in other classifiers, in particular $i$ 'SIT(1)' and $i$ 'LIE(2)'. This is another case of analogical relations being drawn without respect to classifier-internal morphological structure; the comparable classifiers have the $i$ vowel, though it is not determined by [FRONT, HIGH] 
Table 3.9. Classifier stem paradigm for $f a$ ' $\mathrm{wATCH}(28)$ '

\begin{tabular}{|c|c|c|c|c|c|c|}
\hline & & га 'พАTсH(28)' & $\begin{array}{l}\text { INNER } \\
\text { STEM: }\end{array}$ & $\begin{array}{l}\text { fa DEFAULT } a \\
\varnothing \text { C:WEAK }\end{array}$ & C:GEMINATE & \\
\hline & & NFUT (/PRSL) & & IRR (/FUT) & PST & PSTIRR \\
\hline SG & $\begin{array}{l}1 \\
2 \\
3\end{array}$ & $\begin{array}{l}\text { yirayan } \\
\text { y-i-[DEF]-nan } \\
\text { tirayan } \\
\text { t-... } \\
\text { diranan / kiranan } \\
\text { d-.../ k-... }\end{array}$ & $\begin{array}{r}\text { SG } 1 \\
2\end{array}$ & $\begin{array}{l}\text { nira } \\
\text { n-i-[DEF] }-\varnothing \\
\text { tira } \\
\text { t-... } \\
\text { kira / pira } \\
\text { k-.../ p-... }\end{array}$ & $\begin{array}{l}\text { nira } \\
\text { n-i-[DEF]- } \varnothing \\
\text { tira } \\
\text { t- } \ldots \\
\text { dira } \\
\text { d- }-\ldots\end{array}$ & $\begin{array}{l}\text { nirani } \\
\text { n-i-[DEF]-ni } \\
\text { tirani } \\
\text { t-... } \\
\text { dirani } \\
\text { d- } \ldots\end{array}$ \\
\hline INCL & $1+2$ & $\begin{array}{l}\text { tiranan } \\
\text { t-i-[DEF]-nan }\end{array}$ & $\begin{array}{r}\text { INCL } \\
1+2\end{array}$ & $\begin{array}{l}\text { pira } \\
\text { p-i-[DEF] }]-\varnothing\end{array}$ & $\begin{array}{l}\text { tira } \\
\text { t-i- }[\mathrm{DEF}]-\varnothing\end{array}$ & $\begin{array}{l}\text { tirani } \\
\text { t-i-[DEF]-ni }\end{array}$ \\
\hline \multirow[t]{2}{*}{$\mathrm{PL} / \mathrm{DU}$} & $\begin{array}{l}1 \\
2 \\
3\end{array}$ & $\begin{array}{l}\text { nanan } \\
\text { n-a-[WEAK] }] \text {-nan } \\
\text { nanam } \\
\text { n-... } \\
\text { panam / kanam } \\
\text { p-.../ k-... }\end{array}$ & $\begin{array}{r}\text { PL } 1 \\
\\
2\end{array}$ & 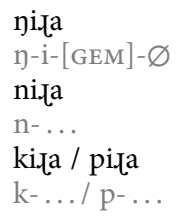 & 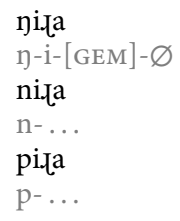 & $\begin{array}{l}\text { ni._ani } \\
\text { n-i-[GEM]-ni } \\
\text { ni._ani } \\
\text { n-... } \\
\text { pi._ani } \\
\text { p-... }\end{array}$ \\
\hline & & & DU 1 & $\begin{array}{l}\text { ni._a } \\
\text { n-i-[GEM]- } \varnothing \\
\text { ni._a } \\
\text { n-... } \\
\text { ki._a / pi._a } \\
\text { k-.../p-... }\end{array}$ & $\begin{array}{l}\text { ni._a } \\
\text { n-i-[GEM] }-\varnothing \\
\text { ni._a } \\
\text { n-... } \\
\text { pi._a } \\
\text { p-... }\end{array}$ & $\begin{array}{l}\text { ni._ane } \\
\text { n-i-[GEM]-ne } \\
\text { ni._ane } \\
\text { n-... } \\
\text { pi._ane } \\
\text { p-... }\end{array}$ \\
\hline
\end{tabular}

alternations on an inner stem, but rather by an underlying inner stem vowel (visible not in the default stem form, but only in forms with suppletive StemC). Therefore the analogical mechanism depends on a shared morphosyntactic category 3PL.NFUT, and on some shared formatives, but ignores the patterns of inner stem vowel defaults and alternations existent in other parts of the paradigm. Again it draws a phonological analogy that abrogates inner stem/affix structure.

In historical reconstruction, 'demorphologization' has been used to describe phonological material that at one point constitutes a regular, predictable morpheme, and at some later point loses its connection to morphological patterns from which it derived. For example, the final rime of seldom derives from Old English dative *-um, while the $m$ in French rompre 'break' derives from a nasal infix associated with present tense in Latin (Klausenburger 1976; Hopper 1990). Each of these was once an inflectional exponent, because it was part of a form:meaning pattern shared by an inflectional class of lexemes, but the dissolution of these patterns has left them absorbed into lexical stems. The recent innovations observed in Murrinhpatha 1sG.Do(34).PST and 3PL.WATCH(28).NFUT do not begin from a clear 'morphemic' unit in this way, as predictable form:meaning 
relations in the classifier stem morphology have already long given way to lexically specific, unpredictable allomorphy. But the changes nonetheless reflect incremental steps on the path of demorphologization, undermining the morphological structure of the classifier stem. Every time a paradigmatic cell in the system shifts from a more predictable allomorph to a less predictable one, the formative structure of the system is incrementally undermined. Processes of this type are probably responsible for much of the integrative complexity in Murrinhpatha verbs-though pursuit of this hypothesis would depend on more extensive historical reconstruction than is presently available (Green 2003).

\subsection{Conclusions}

In this chapter, we have investigated changes in Murrinhpatha classifier stem paradigms, a closed-class system with high integrative complexity. The system of intersecting formatives underlying the exponence of person, number, and tense on Murrinhpatha verb classifier stems is unusually complex, in terms of both wealth of allomorphy and unpredictability of paradigmatic relations. We have studied changes unfolding in this system with the goal of determining whether observed changes reduce or increase the complexity of the system. Seven likely changes in progress were identified, based on variable exponents where younger speakers showed a strong preference for an innovative variant, as opposed to the conservative variant favoured by older speakers. Calculation of the most predictable allomorphs for these exponents was performed by adapting the model of Ackerman \& Malouf (2015), but none of the seven observed changes were selected as expected by this model. Nor were the changed forms more predictable than the incumbent forms they replaced-in fact, in six of the seven instances, the innovated form was less predictable. Analysis of the analogical sources for two of the forms suggests that less predictable forms have been selected by speakers because of analogies that abrogate the inner stem/affix structure evident in the system. The extensive phonological mutation already undergone by the inner stem elements has no doubt led to this further obfuscation of inner stem elements, deepening the overall complexity of the system.

Incremental demorphologization produces integrative complexity, but also adds to opacity in structure. We have observed this in a closed-class system of thirty-nine members, but also argued that the problem of integrative complexity presupposes a closed class of some size. The size of the Murrinhpatha paradigms, with 1,638 forms in total, presumably allows for some degree of whole-form memorization. But evidence observed in analogical changes also shows that implicational relations are active in acquisition or processing, and not all forms are learnt and stored in isolation. We hope that further research on integrative complexity will provide more insight into how analogy and memorization interact in complex inflectional systems. 


\section{Appendix}

Illustrated below are the inflectional paradigms for classifiers discussed in this chapter. The paradigms for Do(34) and $\operatorname{wATCH}_{28}$ are illustrated in the body of the text.

\begin{tabular}{|c|c|c|c|c|c|c|}
\hline & \multicolumn{2}{|r|}{$/ ø /$ 'SIT(1)' } & \multirow[t]{2}{*}{$\begin{array}{l}\text { INNER } \\
\text { STEM: }\end{array}$} & \multicolumn{2}{|c|}{$\begin{array}{l}/ \varnothing / \text { DEFAULT } \\
/ \text { /i/ C:RHOTIC } \\
\text { /ju/ C:J (SUPPL), VH:BACK }\end{array}$} & \multirow[b]{2}{*}{ PSTIRR } \\
\hline & & $\begin{array}{l}\text { NFUT } \\
\text { (/PRSL) }\end{array}$ & & IRR (/FUT) & PST & \\
\hline SG & $\begin{array}{l}1 \\
2 \\
3\end{array}$ & $\begin{array}{l}\text { nem } \\
\text { n-e-[DEF] }-\mathrm{m} \\
\text { tim } \\
\text { t-i- }[\mathrm{DEF}]-\mathrm{m} \\
\operatorname{dim} / \mathrm{kem} \\
\mathrm{d}-\mathrm{i}-[\mathrm{DEF}]-\mathrm{m} / \mathrm{k} \\
-\mathrm{e}-[\mathrm{DEF}]-\mathrm{m}\end{array}$ & $\begin{array}{r}\text { SG } 1 \\
2 \\
3\end{array}$ & $\begin{array}{l}\text { ni } \\
\text { n-i-[DEF] }-\varnothing \\
\mathrm{ti} \\
\mathrm{t}-\ldots \\
\mathrm{ki} / \mathrm{pi} \\
\mathrm{k}-\ldots / \\
\mathrm{p}-\ldots\end{array}$ & $\begin{array}{l}\text { nini } \\
\text { y-i-[DEF]-ni } \\
\text { țini } \\
\text { t-... } \\
\text { dini } \\
\text { d-... }\end{array}$ & $\begin{array}{l}\text { nini } \\
\text { n-i-[DEF]-ni } \\
\text { tini } \\
\text { t-... } \\
\text { dini } \\
\text { d-... }\end{array}$ \\
\hline INCL & $1+2$ & 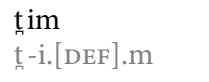 & $\begin{array}{r}\text { INCL } \\
1+2\end{array}$ & $\begin{array}{l}\text { pi } \\
p-i .[D E F] . \varnothing\end{array}$ & $\begin{array}{l}\text { tini } \\
\text { t-i- }-[D E F]-n i\end{array}$ & $\begin{array}{l}\text { tini } \\
\text { t-i-[DEF]-ni }\end{array}$ \\
\hline \multirow[t]{2}{*}{$\begin{array}{l}\mathrm{PL} / \\
\mathrm{DU}\end{array}$} & $\begin{array}{l}2 \\
3\end{array}$ & $\begin{array}{l}\text { narim } \\
\text { n-a-[RHOT]-m } \\
\text { nirim } \\
\text { n-i-[RHOT]-m } \\
\text { pirim / karim } \\
\text { p-i-[RHOT }]-m \text { / } \\
\text { k-a-[RHOT }]-m\end{array}$ & PL 1 & $\begin{array}{l}\text { nuju } \\
\text { n-u-[J. } \\
\text { BACK]- } \varnothing \\
\text { nuju } \\
\text { n-... } \\
\text { kuju / puju } \\
\text { k-.../ } \\
\text { p-... }\end{array}$ & $\begin{array}{l}\text { narini } \\
\text { n-a-[RHOT]-ni } \\
\text { nirini } \\
\text { n-i-[RHOT] }- \text { ni } \\
\text { pirini } \\
\text { p-i-[RHOT] }] \text {-ni }\end{array}$ & $\begin{array}{l}\text { narini } \\
\text { n-a-[RHOT]-ni } \\
\text { nirini } \\
\text { n-i-[RHOT]-ni } \\
\text { pirini } \\
\text { p-i-[RHOT]-ni }\end{array}$ \\
\hline & & & DU 1 & $\begin{array}{l}\text { ne } \\
\text { ne. }[\mathrm{DEF}] . \varnothing \\
\text { ne } \\
\text { n- } . . \\
\text { ke / pe } \\
\mathrm{k}-\ldots / \mathrm{p}-\ldots\end{array}$ & $\begin{array}{l}\text { narine } \\
\text { n-a-[RHOT]- } \\
\text { ne } \\
\text { nirine } \\
\text { n-i-[RHOT]-ne } \\
\text { pirine } \\
\text { p-i-[RHOT]-ne }\end{array}$ & $\begin{array}{l}\text { narine } \\
\text { n-a-[RHOT]- } \\
\text { ne } \\
\text { nirine } \\
\text { n-i-[RHOT]-ne } \\
\text { pirine } \\
\text { p-i-[RHOT]-ne }\end{array}$ \\
\hline
\end{tabular}




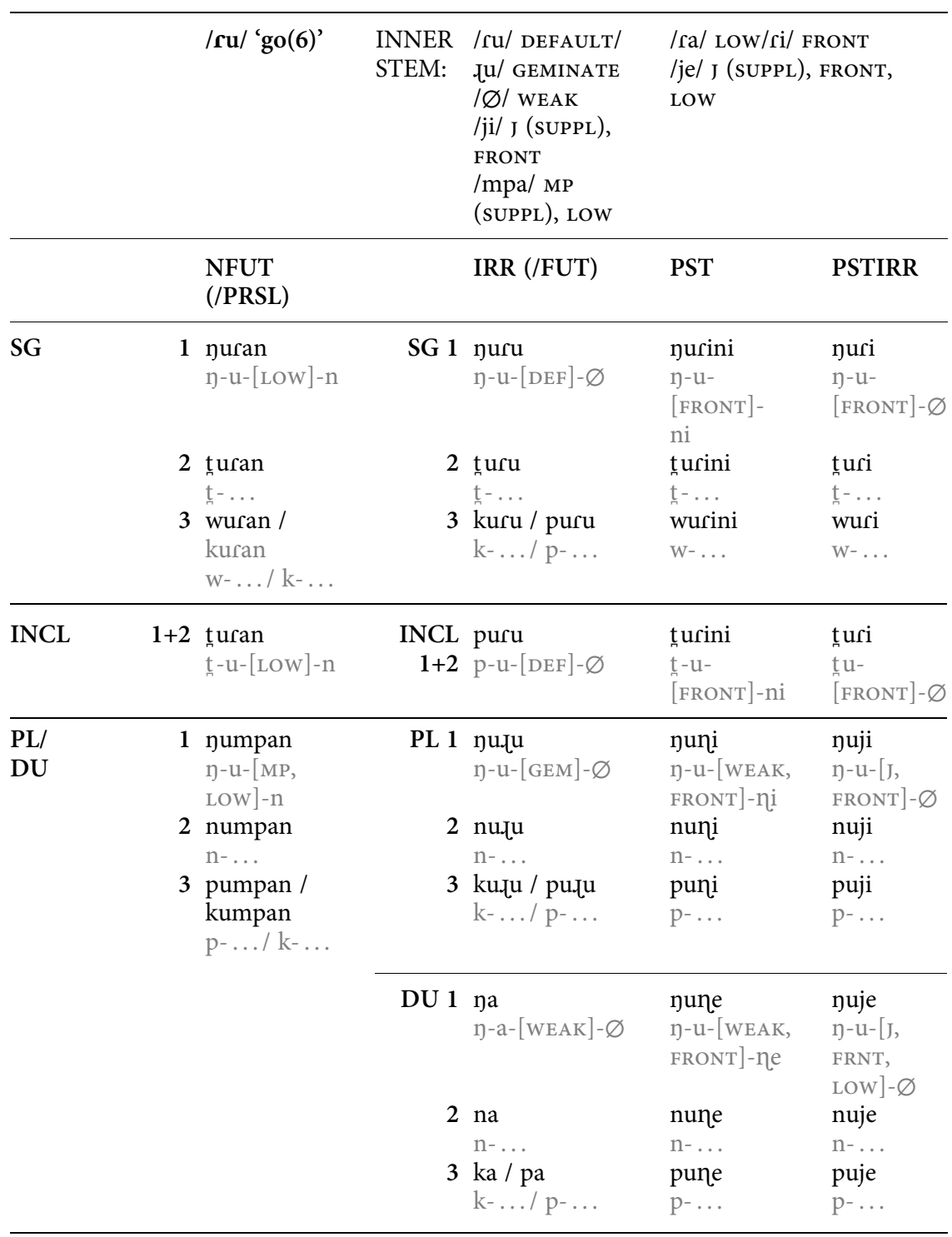




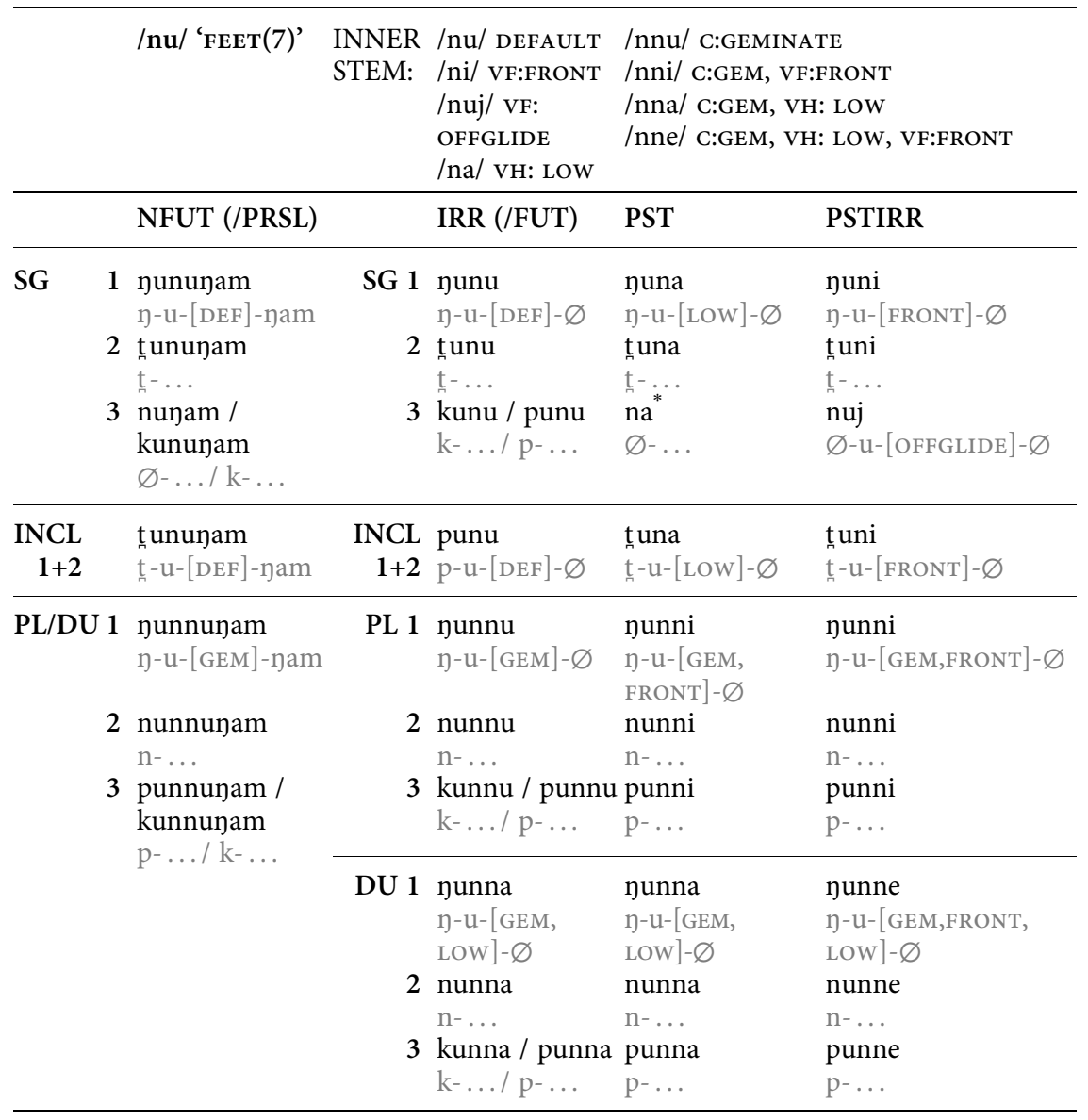

Note: Street (1987) in addition lists a variant /nu.ja/ use.feet.3sG.PST. This variant does not appear in our corpus data.

\begin{tabular}{|c|c|c|c|c|c|c|}
\hline & \multirow{2}{*}{\multicolumn{2}{|c|}{$\begin{array}{l}\text { /la/ 'WIPE(26)' } \\
\text { NFUT (/PRSL) }\end{array}$}} & \multicolumn{4}{|c|}{$\begin{array}{l}\text { INNER /la/ DEFAULT/lla/ C:GEMINATE } \\
\text { STEM: }\end{array}$} \\
\hline & & & & IRR (/FUT) & PST & PSTIRR \\
\hline SG & $\begin{array}{l}1 \\
2 \\
3\end{array}$ & $\begin{array}{l}\text { nilam } \\
\text { Ø-i-[DEF]-m } \\
\text { tilam } \\
\text { t-... } \\
\text { dilam / kilam } \\
\text { d-.../ k-... }\end{array}$ & $\begin{array}{r}\text { SG } 1 \\
2 \\
3\end{array}$ & $\begin{array}{l}\text { nila } \\
\text { y-i-[DEF]- } \varnothing \\
\text { tila } \\
\mathrm{t}-\ldots \\
\text { kila / pila } \\
\text { k- .../ p- ... }\end{array}$ & $\begin{array}{l}\text { nila } \\
\text { y-i-[DEF] }]-\varnothing \\
\text { tila } \\
\text { t- }-\ldots \\
\text { dila } \\
\text { d- } \ldots\end{array}$ & $\begin{array}{l}\text { nila } \\
\text { nin-i-[DEF]-ni } \\
\text { tilani } \\
\text { t-i-[DEF]-ni } \\
\text { dilani } \\
\text { d-i-[DEF]-ni }\end{array}$ \\
\hline INCL & $1+2$ & $\begin{array}{l}\text { tilam } \\
\text { th-i-[DEF] }-\mathrm{m}\end{array}$ & $\begin{array}{r}\text { INCL } \\
1+2\end{array}$ & $\begin{array}{l}\text { pila } \\
\text { p-i-[DEF]- } \varnothing\end{array}$ & $\begin{array}{l}\text { tila } \\
\text { t-i-[DEF] }-\varnothing\end{array}$ & $\begin{array}{l}\text { tilani } \\
\text { t-i-[DEF]-ni }\end{array}$ \\
\hline $\mathrm{PL} / \mathrm{DU}$ & $\begin{array}{l}1 \\
2\end{array}$ & $\begin{array}{l}\text { nillanam } \\
\text { ฤ-i-[GEM]-nam } \\
\text { nillanam } \\
n-\ldots\end{array}$ & $\begin{array}{r}\text { PL } 1 \\
2\end{array}$ & $\begin{array}{l}\text { nilla } \\
\text { n-i-[GEM] }-\varnothing \\
\text { nilla } \\
\text { n-... }\end{array}$ & $\begin{array}{l}\text { nilla } \\
\text { n-i-[GEM] }-\varnothing \\
\text { nilla } \\
\text { n-... }\end{array}$ & $\begin{array}{l}\text { nillani } \\
\text { n-i-[GEM]-ni } \\
\text { nillani } \\
\text { n-... }\end{array}$ \\
\hline
\end{tabular}


3 pillanam / killanam $\mathrm{p}-\ldots / \mathrm{k}-\ldots$.

\begin{tabular}{|c|c|c|c|}
\hline 3 & $\begin{array}{l}\text { killa / pilla } \\
\mathrm{k}-\ldots / \mathrm{p}-\ldots\end{array}$ & $\begin{array}{l}\text { pilla } \\
\text { p- ... }\end{array}$ & $\begin{array}{l}\text { pillani } \\
\text { p- ... }\end{array}$ \\
\hline DU 1 & nilla & nilla & nillani \\
\hline & $\eta-\mathrm{i}-[\mathrm{GEM}]-\varnothing$ & $\eta-i-[G E M]-\varnothing$ & $\eta-\mathrm{i}-[\mathrm{GEM}]-\eta \mathrm{i}$ \\
\hline 2 & nilla & nilla & nillani \\
\hline & n- . & $\mathrm{n}-\ldots$ & $\mathrm{n}-$. \\
\hline 3 & killa / pilla & pilla & pillani \\
\hline & p-.. & p-. & $\mathrm{p}-\ldots$ \\
\hline
\end{tabular}

\begin{tabular}{|c|c|c|c|c|c|c|}
\hline & \multirow{2}{*}{\multicolumn{2}{|c|}{$\begin{array}{l}\text { /ra/ 'WATCH.RR (36) } \\
\text { NFUT (/PRSL) }\end{array}$}} & \multicolumn{4}{|c|}{ 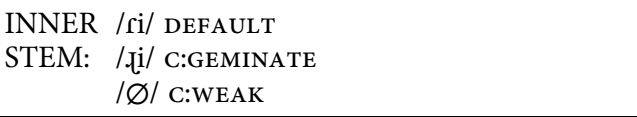 } \\
\hline & & & & IRR (/FUT) & PST & PSTIRR \\
\hline SG & $\begin{array}{l}1 \\
2 \\
3\end{array}$ & $\begin{array}{l}\text { nirim } \\
\text { y-i-[DEF]-m } \\
\text { tirim } \\
\text { t-... } \\
\text { dirim / kirim } \\
\text { d-.../ k-... }\end{array}$ & $\begin{array}{r}\text { SG } 1 \\
2 \\
3\end{array}$ & $\begin{array}{l}\text { niri } \\
\text { n-i-[DEF]- } \varnothing \\
\text { țiri } \\
\text { t-... } \\
\text { kiri / piri } \\
\text { k-... p- ... }\end{array}$ & $\begin{array}{l}\text { niri } \\
\text { n-i-[DEF] }] \varnothing \\
\text { țiri } \\
\text { t-... } \\
\text { diri } \\
\text { d- } \ldots\end{array}$ & $\begin{array}{l}\text { nirini } \\
\text { y-i-[DEF }]-n i \\
\text { țirini } \\
\text { t-... } \\
\text { dirini } \\
\text { d- }-\ldots\end{array}$ \\
\hline INCL & $1+2$ & $\begin{array}{l}\text { tirim } \\
\text { t-i- }-[D E F]-m\end{array}$ & $\begin{array}{r}\text { INCL } \\
1+2\end{array}$ & $\begin{array}{l}\text { piri } \\
\text { p-i-[DEF] }]-\varnothing\end{array}$ & $\begin{array}{l}\text { tiri } \\
\text { tr-i-[DEF }]-\varnothing\end{array}$ & $\begin{array}{l}\text { tirini } \\
\text { t-i-[DEF]-ni }\end{array}$ \\
\hline \multirow[t]{2}{*}{$\mathrm{PL} / \mathrm{DU}$} & $\begin{array}{l}1 \\
2 \\
3\end{array}$ & $\begin{array}{l}\text { nim } \\
\text { n-i-[WEAK]-m } \\
\text { nim } \\
\text { n-... } \\
\text { pim / kim } \\
\text { p-.../k-... }\end{array}$ & $\begin{array}{r}\text { PL } 1 \\
2 \\
3\end{array}$ & 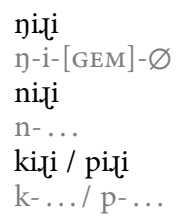 & $\begin{array}{l}\text { ni } \\
\text { n-i-[WEAK }]-\varnothing \\
\text { ni } \\
\text { n- ... } \\
\text { pi } \\
\text { p- } \ldots\end{array}$ & 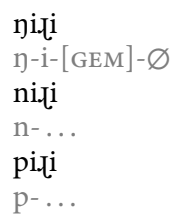 \\
\hline & & & $\begin{array}{r}\text { DU } 1 \\
2 \\
3\end{array}$ & 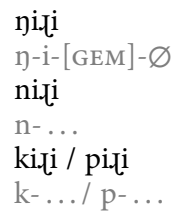 & $\begin{array}{l}\text { ni } \\
\text { n-i-[WEAK }]-\varnothing \\
\text { ni } \\
\text { n- ... } \\
\text { pi } \\
\text { p- ... }\end{array}$ & 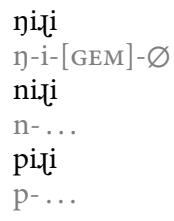 \\
\hline
\end{tabular}




\section{Acknowledgements}

This research is funded by the Australian Research Council Centre of Excellence for the Dynamics of Language (Project ID: CE140100041). We are greatly indebted to the people of Wadeye, Australia, who have generously shared their knowledge of Murrinhpatha with us. We also thank Peter Arkadiev and Francesco Gardani for inviting us to present at the workshop which led to this volume, and for their comments on our original submission. Bill Forshaw, Jeff Parker, and an anonymous reviewer also provided insightful comments, as did audience members of the 'Morphological Complexity' workshop at Societas Linguistica Europaea (SLE), 2015. We dedicate this chapter to the late Chester Street, whose detailed documentation work revealed the extraordinary complexity of Murrinhpatha verbs. 


\section{University Library}

\section{- M M I N E R VA A gateway to Melbourne's research publications}

Minerva Access is the Institutional Repository of The University of Melbourne

Author/s:

Mansfield, J;Nordlinger, R

Title:

Demorphologization and deepening complexity in Murrinhpatha.

Date:

2020-09-24

Citation:

Mansfield, J. \& Nordlinger, R. (2020). Demorphologization and deepening complexity in Murrinhpatha.. Arkadiev, P (Ed.). Gardani, F (Ed.). The Complexities of Morphology, (1), pp.52-80. Oxford University Press.

Persistent Link:

http://hdl.handle.net/11343/267293 